\title{
THE RELATIONSHIP BETWEEN SENSE OF COMMUNITY AND AGREEABLENESS WITH PROSOCIAL BEHAVIOR AMONG MEMBER OF YOUNG ON TOP (YOT)
}

\author{
Ariska Tri Devia, Munawir Yusuf ${ }^{b}$, Hardjono $^{c}$ \\ ${ }^{\mathrm{abc}}$ Department of Psychology, Faculty of Medicine, Sebelas Maret University, Indonesia \\ E-mail: ariskatd@gmail.com
}

\begin{abstract}
Helping behavior that benefits others or society in general called as prosocial behavior. Pro social behavior refers to voluntary actions that are intended to help and give benefit for another individual or group. Prosocial behavior in the individual in a community or organization can be affected by sense of community and agreeableness. The aim of this study is to determine: (1) the relationship between sense of community and agreeableness with prosocial behavior, (2) the relationship between sense of community with prosocial behavior, and (3) the relationship between agreeableness with prosocial behavior among member of Young On Top (YOT). The population of this study is member of Young On Top (YOT) region Joglosemar-Jatim 2015 which is divided in six cities, those are in Solo, Semarang, Jogja, Malang, Jember, and Surabaya. Sampling used population studies or census by using the entire population consisting 162 members. Instrument in this study used prosocial behavior scale, sense of community scale, and agreeableness scale using Indonesian version of BFI. Multiple regression analysis was used for examining the first hypothesis, and partial correlation test for examining the second and the third hypothesis. The result of this study showed that there was a significant positive correlation between sense of community and agreeableness with prosocial behavior among member of Young On Top (YOT) (F-test = 100,875; $\mathrm{p}<0,05$; and $\mathrm{R}=0,784)$. Partially, the result shows the significant positive correlation between sense of community and prosocial behavior $(\mathrm{r}=0,660 ; \mathrm{p}<0,05)$, and there is significant positive correlation between agreeableness and prosocial behavior $(r=0,244 ; \mathrm{p}<0,05)$. The value of $\mathrm{R} 2$ in this study is 0,559 or $55,9 \%$ which was of effective contribution of sense of community towards prosocial behavior with amount $47,26 \%$ and effective contribution of agreeableness towards prosocial behavior with amount $8,67 \%$.
\end{abstract}

Key word: prosocial behavior, sense of community, agreeableness

Globalization makes the behaviors that often appear likely to lead to negative things like individualistic, selfish, and has nature of contractual relationship based solely on profit-loss and exploitation (Yuwono, 2009). But in essence, whatever degree of human's independence, they would still need help for others at certain moments (Faturochman in Sabiq \& Djalali, 2012).

People need to help each other in order to survive. Behavior that refer to voluntary and deliberate actions specifically intended to benefit or improve the wellbeing of another called as prosocial behavior. Eisenberg and Mussen (1989) define prosocial behavior as a behavior that is voluntary and deliberate that has positive consequences for the well-being of another person or group. These actions are made by empathy and by a sense of concern about others' well-being and rights. Prosocial behavior consists of six aspects, such as helping, sharing, generosity, donating, cooperative, and honesty.

Prosocial behavior can determine interaction and the formation of relationships between individuals, it can even makes the community thrive (Singh \& Teoh, 2013), can improves self-esteem, helps in psychosocial adaptation, and gets experience that makes positive feeling like grateful (Caprara \& Steca, 2005). Prosocial behavior was also can prevents social conflicts (Sunarwiyati in Kartono, 2005) as well as reducing the potential of depression and anxiety (Krause, 2009).

McGinley and Carlo (2007) explains that prosocial behavior at the individual associated with a poor social adjustment such rejection. Chen et al. (2002) adds that individuals who are less involved in prosocial behaviors are more likely to engage in aggressive behavior and antisocial behavior. Antisocial behavior is a behavior that has the intent to hurt or harm others.

Farrington (in Millie, 2009) said that, at this time anti-social behavior happens a lot and seemed become a normal thing. The Central Statistics Agency (BPS) in 2015 published that from 2008 to 2014 there has been a fairly rapid increase in cases of mass clash that occurred on the various elements of society.

Anti-social behavior and aggressive behavior can be reduced by increasing the positive behavior of the 
individual so the harmonious relationship can always be maintained. The positive behaviors such as prosocial behavior (Eisenberg \& Mussen, 1989) need to be built and maintained by the individual.

Gagne (2013) mentions the organization or community is one of many ways to contribute to the society because it can provides an opportunity for individuals to develop prosocial behavior. Prosocial behavior within the organization or community can improve academic achievement, positive self-esteem, positive relationships with others, even higher prosocial behavior than before (Penner et al., 2005).

Interaction that takes place from time to time on a particular social group will create bonding among members. The stronger bond existing can affects, changes, or improves the behavior of the individual (Boner in Gerungan, 1996). These attributes can positively affect a sense of belonging within the individual (Goodenow in Strayhorn, 2012). Sense of belonging in community organization called as sense of community (Royal \& Rossi, 1996).

Brodsky et al. (in Omoto \& Snyder, 2009) reported that individuals who have a sense of community have willing to be active voluntary and be more generous (Kingston et al. in Omoto \& Snyder, 2009). Besides, Cuthill (2002) states that when there is a sense of community, individuals will have more interest in public.

Sense of community is a feeling that is owned by members of a community to look after each other in the group, and the mutual trust that each member needs will be met through shared commitment (McMillan \& Chavis, 1986). Sense of community consists of four aspects, namely membership, influence, integration and fulfillment of needs, and shared emotional connection.

For individuals, the sense of community can be a positive sign of social progress (Connell et al., in Evans, 2007) and well-being (Pretty et al., 2006). Other studies have shown that individuals with a strong sense of community will have low feeling of loneliness and the behavior of crime tends to decrease (Chipuer, 2001), get advantages in performance, good retention (Thomas, 2012), increasing the social networks, as well as improving ability to manage problems in the community or organization (Berkman \& Glass, 2000). While the absence of a sense of community can make people in the community feel isolated, alienated, and feel alone (Farrell et al., 2004).

Basically, when two people have some similarity, the bond between the two can be intertwined and can lead to prosocial behavior (Lichtenbarger, 2000). However, prosocial behavior not only happened by sense of community. Another thing affecting prosocial behavior are personality traits of the individual. Tendency of individuals to behave in prosocial generally settled in personality and temperament (Caspi et al., 2003).

Trait theory is one way to understand the personality of the individual. The trait is grouped into five models called Five Factor Model or Big Five. According to McCrae and Costa (1996) five models of personality are agreeableness, extraversion, openness, conscientiousness, and neuroticism. Among the five model of personality, Caprara et al. (2012) states that agreeableness is the main model of personality that has a positive influence on the prosocial behavior of individuals.

John and Srivastava (1999) revealed that agreeableness is one of personality dimension from big five model that is synonymous with social adaptation, pleasant, sincere friendship, kindness, and love. Agreeableness is divided into five aspects, namely altruism, compliance, modesty, tender-mindedness and trust. Research Carlo et al. (2005) states that there is a significant positive relationship between agreeableness with the voluntary activities as a part of prosocial behavior.

Graziano et al. (2007) found that individuals with high agreeableness has higher empathy, usually have high social natures (Mount et al., 2005), more friendly and generous in negotiating to keep the feelings of others, and has a tendency to work together and maintain social harmony (Hussain et al., 2012 ). Individuals with high agreeableness is characterized by behaviors that tend to be warmer, have good social relationships, compassion, and love to help others (Lepine \& Van Dyne, 2001). On the other hand, individuals with low agreeableness is associated with high aggression (Miller et al., 2009), tend to be selfish, not worry about other people, unfriendly and rude in social relationships, as well as having a high suspicion for others (Hussain et al., 2012).

Based on the introduction above, it is necessary to have study on "The relationship between Sense of Community and Agreeableness with Prosocial Behavior among Member of Young On Top (YOT)".

\section{METHOD}

Population in thus research is the member of Young On Top in some cities such as Yogyakarta, Solo, Semarang, Surabaya, Jember, and Malang (JoglosemarJatim) in 2015 that consisting of 162 peoples. Sampling in this research used census population studies or entire studies.

Collecting data method was a quantitative approach using prosocial behavior scale, sense of community scale, and agreeableness scale. Prosocial behavior scale constructed based on the aspects raised by Eisenberg and Mussen (1989), which is helping, sharing, generosity, donating, cooperative, and honesty. 
Sense of community scale constructed based on the aspects by McMillan and Chavis (1986), which is membership, influence, integration and fulfillment of needs, and shared emotional connection. Agreeableness scale refers to the Big Five Inventory (BFI) which has been translated into Indonesian by Ramdhani (2012) on the basis of aspects put forward by John \& Srivastava (1999), which are altruism, compliance, modesty, tender-mindedness and trust.

Calculation of scale validity used Corrected Item Total Correlation by aborting item that has a correlation coefficient below 0.3. Reliability test used Cronbach Alpha formula. Based on the results of validity and reliability test, these scale consisted of 28-item for prosocial behavior scale with reliability coefficient 0.877 ; 31-item for sense of community scale with reliability coefficient 0.906 ; 7 -item agreeableness scale with reliability coefficient 0.753 .

\section{FINDING AND DISCUSSION}

\section{Findings}

The results proved that first hypothesis is accepted, there is a positive and significant relationship between sense of community and agreeableness with prosocial behavior.

Table 1. Simultaneous Test Results

ANOVA $^{b}$

\begin{tabular}{llrrrrr}
\hline Model & & Sum of Squares & df & Mean Square & F & \multicolumn{1}{c}{ Sig. } \\
\hline 1 & Regression & 4731,130 & 2 & 2365,565 & 100,874 &, $000^{\mathrm{a}}$ \\
& Residual & 3728,648 & 159 & 23,451 & & \\
& Total & 8459,778 & 161 & & & \\
\hline
\end{tabular}

\section{a. Predictors: (Constant), Agreeableness, Sense of Community \\ b. Dependent Variable: Prosocial Behavior}

From the table above, we can conclude that the results of hypothesis test using multiple linear regression showed a value of 0.000 (or 0.0001 ) with a significance level of 0.05 and value Ftest 100.874 with Ftable 3.05, stated that the $\mathrm{p}<0.05$ and Ftest $>$ Ftable.

The result of partial correlation test proved that the second and third hypothesis in the study are accepted.

Table 2. The Result of Partial Correlation Test between Sense of Community and Prosocial Behavior

\begin{tabular}{lllcc}
\hline \multicolumn{4}{c}{ Correlations } \\
\hline Control Variables & \multicolumn{3}{c}{ Prosocial Behavior } & Sense of Community \\
\hline Agreeableness & $\begin{array}{l}\text { Prosocial } \\
\text { Behavior }\end{array}$ & $\begin{array}{l}\text { Correlation } \\
\text { Significance } \\
\text { (2-tailed) }\end{array}$ & 1,000 &, 660 \\
& $\begin{array}{l}\text { df } \\
\text { Sense of } \\
\text { Community }\end{array}$ & Correlation & 0 &, 000 \\
& $\begin{array}{l}\text { Significance } \\
(2 \text {-tailed })\end{array}$ &, 660 & 159 \\
& df &, 000 & 1,000 \\
& & 159 & 0 \\
\hline
\end{tabular}

The result of partial correlation test in the table above showed that the variable sense of community has a significance of 0.000 (or 0.0001), at the 0.05 significance level $(p$-value $<0.05)$. It means there is significant relationship between the sense of community with prosocial behavior among member of Young On
Top (YOT). These results have a positive relationship direction, so it can be said that the higher level of sense of community you have, the higher level of prosocial you have. 
Table 3. The Result of Partial Correlation Test between Agreeableness and Prosocial Behavior

\begin{tabular}{|c|c|c|c|c|}
\hline \multicolumn{5}{|c|}{ Correlations } \\
\hline \multicolumn{2}{|c|}{ Control Variables } & & Prosocial Behavior & Agreeable-ness \\
\hline \multirow{7}{*}{$\begin{array}{l}\text { Sense of } \\
\text { Community }\end{array}$} & \multirow{4}{*}{$\begin{array}{l}\text { Prosocial } \\
\text { Behavior }\end{array}$} & Correlation & 1,000 & ,244 \\
\hline & & & & \\
\hline & & $\begin{array}{l}\text { Significance } \\
\text { (2-tailed) }\end{array}$ & . & ,002 \\
\hline & & df & 0 & 159 \\
\hline & \multirow{3}{*}{$\begin{array}{l}\text { Agreeable- } \\
\text { ness }\end{array}$} & Correlation & ,244 & 1,000 \\
\hline & & $\begin{array}{l}\text { Significance } \\
\text { (2-tailed) }\end{array}$ & ,002 & . \\
\hline & & df & 159 & 0 \\
\hline
\end{tabular}

The result of partial correlation test in the table above shows that the variable agreeableness has a significance of 0.002 at a significance level of 0.05 ( $\mathrm{p}$-value $<0.05$ ). It means there is significant relationship between agreeableness with prosocial behavior among member of Young On Top (YOT). These results have a positive relationship direction, so it can be said that the higher level of agreeableness you have, the higher level of prosocial you have.

The relative contribution of sense of community toward prosocial behavior is $84.5 \%$, while the relative contribution of agreeableness toward prosocial behavior is $15.5 \%$. Effective contribution of sense of community toward prosocial behavior is $47.26 \%$, while the effective contribution of agreeableness toward prosocial behavior is $8.67 \%$.

Descriptive analysis showed that generally there was $6.17 \%$ of respondents in moderate level of prosocial behavior, $83.33 \%$ in high level, and $10.5 \%$ in level very high. In variable sense of community, there was $0.62 \%$ of respondents in low level, 33, 95\% in moderate level, $57.41 \%$ in high level, and $8.02 \%$ in very high level. In variable agreeableness, there was $78.4 \%$ respondents in high level and $21.6 \%$ in very high level.

Based on the explanation above, this research has been able to answer the research hypothesis, that there is significant relationship between sense of community and agreeableness with prosocial behavior among member of Young On Top (YOT) either together or partially.

\section{Discussion}

The first hypothesis in this study is accepted, shows that there is significant positive relationship between sense of community and agreeableness with prosocial behavior among member of Young On Top (YOT). Arkelof and Kranton (in Baldassarri \& Grossman, 2014) said that when an individual has a sense of community, they would tend to indicate the expected behavior by members of his group. It can boost the potential of the behaviors leading to prosocial behavior (Nolin, 2010), even Goeree (2010) added that when individuals have such a relation to groups that is followed, he would be very willing to share and show prosocial behavior in greater way.

Agreeableness also able to predict prosocial behavior among member of Young On Top (YOT). According to Graziano and Eisenberg (in Carlo et al., 2005) agreableness is a core factor or the most important factor that has contribution to prosocial behavior of individuals. Individual with agreeableness according to Yarkoni et al. (2015) has a strong compassion to the response thus more likely to help someone.

The second hypothesis in this study can be accepted, that there is significant positive relationship between sense of community with prosocial behavior among member of Young On Top (YOT). It can be said that the higher level of sense of community means the higher the level of prosocial behavior. This suggests that the feelings contained in the sense of community like the feeling of caring for each other, mutual trust that the needs of each member will be mutually met through shared commitment, a sense in which individuals feel they have and considered in a network and structure; 
turned out to have a positive relationship with prosocial behavior.

The third hypothesis in this study can be accepted, that there is significant positive relationship between agreeableness with prosocial behavior among member of Young On Top (YOT). It can be said that the higher levels of agreeableness you have, the higher the level of prosocial behavior owned. Personality is one of the factor in prosocial behavior (Sears et al., 1994). Personality can be understood by several approaches, one of that is trait theory or the theory of nature. Trait or characteristic is the size of individual differences in the tendency to show a consistent pattern of thoughts, feelings, and actions (McCrae \& Costa in Cloninger, 2009). Big Five personality trait consisting of openness, conscientiousness, extraversion, agreeablenees, and neuroticism. Among the five personality, Graziano and Eisenberg (1997) states that agreeableness is the most important personality trait that contribute to prosocial behavior. Agreeableness itself by Graziano et al. (In Cote et al., 2011) is characterized by a generous, cooperation, helpfulness, easy to forgive, and has a good quality of warmth.

Coefficient of determination (R2) shows the influence of sense of community and agreeableness with prosocial behavior amounted to 0,559 . This suggests that the effect of sense of community and agreeableness toward prosocial behavior have a presentation at $55.9 \%$. The remaining portion of $44.1 \%$ is influenced by other factors outside the research.

\section{REFERENCES}

Badan Pusat Statistik. (2015). Statistik kriminal 2015. Diambil dari https://www.bps.go.id/website/pdf publikasi/Statistik-Kriminal-2015.pdf

Baldassarri, D., \& Grossman, G. (2014). The effect of group attachment and social position on prosocial behavior. Evidence from lab-in-thefield experiments. Social Structure and Prosocial Behavior, 8(3), 1-9. doi: 10.1371/journal. pone. 0058750 .

Berkman, L., \& Glass, T. (2000). Social integration, social networks, social support, and health. dalam L. Berkman, \& I. Kawachi (Eds.), Social epidemiology. New York: Oxford University Press.

Caprara, G. V., Alessandri, G., \& Eisenberg, N. (2012). Prosociality: The contribution of traits, values, and self efficacy beliefs. Journal of Personality and Social Psychology, 102(2), 1289-1303.

Caprara G. V., \& Steca P. (2005). Self-efficacy beliefs as determinants of prosocial behavior conducive to life satisfaction across ages. Journal of Social and Clinical Psychology, 24, 191-217.
Other factors that can influence prosocial behaviors include self gain, values and norms of the individual, empathy, cost, personality, interpersonal relations, norms of reciprocity, experience and mood, nature of the stimulus, vagueness of responsibility, and levels of need who need help (Staub in Dayakisni \& Hudaniah, 2009).

\section{CONCLUSION AND SUGGESTION}

Based on the analysis of quantitative data obtained through this study it can be concluded that: (1) There are significant positive relationships between sense of community and agreeableness with pro social behavior among member of Young On Top (YOT). (2) There are significant positive correlations between sense of community with pro social behavior among member of Young On Top (YOT). The more positive the sense of community, the higher pro social behavior. (3) There are significant positive correlations between agreeableness with pro social behavior among member of Young On Top (YOT). The higher or more positive agreeableness means equally the higher prosocial behavior. (4) The relative contributions of sense of community toward pro social behavior is $84.5 \%$ and the relative contribution of agreeableness toward pro social behavior is $15.5 \%$. (5) The effective contributions of sense of community toward pro social behavior is $47.26 \%$ and the effective contribution of agreeableness toward pro social behavior is $8.67 \%$.

Carlo, G., Okun, M. A., Knight, G. P., \& De Guzman, M. R. (2005). The interplay of traits and motives on volunteering: Agreeableness, extraversion, and prosocial value motivation. Journal of Personality and Individual Differences, 38, 1293-1305.

Caspi A., Harrington, H., Milne, B., Amell, J. W., Theodore, R.F., \& Moffitt, T.E. (2003). Children's behavioral styles at age 3 are linked to their adult personality traits at age 26. Journal Personal. 71, 495-513.

Chen, X., Liu, M., Rubin, K. H., Cen, G., Gao, X., \& Li, D. (2002). Sociability and prosocial orientation as predictors of youth adjustment: A seven-year longitudinal study in a chinese sample. International Journal of Behavioral Development, 26, 128-136.

Chipuer. H. M. (2001). Dyadic attachments and community connectedness: Links with youth's loneliness experiences. Journal of Community Psychology, 29(4), 429-446. 
Cloninger, S. C. (2009). Theories of personality: Understanding persons, edisi kelima. London: Pearson Practice Hall.

Coté, S., DeCelles, K. A., McCarthy, J. M., Van Kleef, G. A., \& Hideg, I. (2011). The Jekyll and Hyde of emotional intelligence: Emotionregulation knowledge facilitates both prosocial and interpersonally deviant behavior. Journal of Psychological Science, 22(8), 1073-1080.

Cuthill, M. (2002). Coolangatta: A portrait of community well-being. Urban Policy and Research, 20, 187-203.

Dayakisni, T., \& Hudaniah. (2009). Psikologi sosial edisi revisi. Malang: UMM Press.

Eisenberg, N., \& Mussen, P. H. (1989). The root of prosocial in children. New York: Cambridge University Press.

Evans, S. (2007). Youth sense of community: Voice and power in community contexts. Journal of Community Psychology, 35(6), 693-709. doi: 10.1002/jcop. 20173

Farrell, S. J., Aubry, T., \& Coulombe, D. (2004). Neighbourhoods and neighbours: Do they contribute to personal wellbeing?. Journal of Community Psychology, 32(1), 9-25.

Gagne, M. (2003). The role of autonomy support and autonomy orientation in prosocial behavior engagement. Journal of Motivation and Emotion, 27(3), 199-223.

Gerungan, W. A. (1996). Psikologi sosial. Bandung: Eresco.

Goeree, J. K., McConnell, M. A, Mitchell, T., Tromp, T., \& Yariv, L. (2010). The $1 / \mathrm{d}$ law of giving. American Economic Journal: Microeconomics, 2, 183-203.

Graziano, W. G., \& Eisenberg, N. (1997). Agreeableness: A dimension of personality. dalam R. Hogan, S. Briggs, \& J. Johnson (1997) (Eds.), Handbook of personality psychology. San Diego: Academic Press.

Graziano, W. G., Habashi, M. M., Sheese, B. E., \& Tobin, R. M. (2007). Agreeableness, empathy, and helping: A person x situation perspective. Journal of Personality and Social Psychology, 93(4), 583599.

Hussain, S., Abbas, M., Shahzad, K., \& Bukhari, S. A. (2012). Personality and career choices. Journal of Business Management, 6(6), 2255-2260.

John, O. P., \& Srivastava, S. (1999). The big-five trait taxonomy: History, measurement, and theoretical perspectives. dalam L. A. Pervin, \& O. P. John (Eds.), Personality: Theory and research (7th ed.). New York: Guildford Press.

Kartono, K. (2005). Patologi sosial 2: Kenakalan remaja. Jakarta: Rajawali Press.
Krause, N. (2009). Meaning in life and mortality. Journals of Gerontology Series B, Psychological Sciences and Social Sciences, 64, 517-527.

LePine, J. A., \& Van Dyne, L. (2001). Voice and cooperative behavior as contrasting forms of contextual performance: Evidence of differential relationships with big five personality characteristics and cognitive ability. Journal of Applied Psychology, 86(2), 326-336.

Lichtenbarger, D. M. (2000). The effects of similarity on altruism and its relationship to predicted versus actual helping behavior. Department of Psychology, 3, 46-51.

McCrae, R. R., \& Costa, P. T., Jr. (1996). Toward a new generation of personality theories: Theoretical contexts for the five-factor model. dalam Wiggins (Eds.), The five-factor model of personality: Theoretical perspectives. New York: Guilford.

McGinley, M., \& Carlo, G. (2007). Two sides of the same coin? The relations between prosocial and physically aggressive behaviors. Journal of Youth and Adolescence, 37, 337-349.

McMillan, D. W., \& Chavis, D. M. (1986). Sense of community: A definition and theory. Journal of Community Psychology, 14, 6-23.

Millie, A. (2009). Anti-social behavior. United Kingdom: Bell and Bain Ltd.

Miller, C. A., Parrott, D. J., \& Giancola, P. R. (2009). Agreeableness and alcohol-related aggression: The mediating effect of trait aggressivity. Experimental and Clinical Psychopharmacology, 17(6), 445-455.

Mount M. K., Murray R. B., \& Steve M. S. (2005). Higher-order dimensions of the big five personality traits and the big six vocational interest types. Journal of Psychology, 58, 447-478.

Nolin, D. (2010). Food-sharing networks in Lamalera, Indonesia. Human Nature, 21, 243-268.

Omoto, A. M., \& Snyder, M. (2010). Influences of psychological sense of community on voluntary helping and prosocial action. dalam S. Stumer \& M. Snyder (Eds.), The psychology of prosocial behavior: Group processes, intergroup relations, and helping (223-227). New Jersey: Wiley-Balckwell.

Penner, L. A., Dovidio, J. F., Piliavin, J.A., \& Schroeder, D. A. (2005). Prosocial behavior: Multilevel perspectives. Annual Review of Psychology, 56, 365-392.

Pretty, G., Bishop, B., Fisher, A., \& Sonn, C. (2006). Psychological sense of community and its relevance to well-being and everyday life in Australia. Diambil dari The Australian Psychological Society Ltd. website: http://groups.psychology.org.au/ assets/files/community-updated-sept061.pdf 
Royal, M. A., \& Rossi, R. (1996). Individual-level correlates of sense of community: Finings from workplace and school. Journal of Community Psychology, 24, 395-416.

Sabiq, Z., \& Djalali, M. A. (2012). Kecerdasan emosi, kecerdasan spiritual dan perilaku prososial santri pondok pesantren Nasyrul Ulum Pamekasan. Jurnal Psikologi Indonesia, 1(2), 53-65.

Sears, D. O., Fredman, J. L., \& Peplau, L. A. (1994). Psikologi sosial, edisi kelima. Jakarta: Erlangga.

Singh, S., \& Teoh, V. Y. (2013). Enhancing prosocial behavior among college students: Exploring the role of abstract mindset. International Journal of Law and Social Sciences. 3(1), 28-32.

Strayhorn, T. L. (2012). College students' sense of belonging: A key to educational success for all students. New York: Routledge.
Thomas, L. (2012, Juli). Building student engagement and belonging in higher education at a time of change: final report from the what works? Student retention \& success programme.https://www. heacademy.ac.uk/system/files/what_works_final_ report_0.pdf

Yarkoni, T., Ashar, Y. K., \& Wager, T. D. (2015, Agustus). Interactions between donor agreeableness and recipient characteristics in predicting charitable donating and positive social evaluation. Diambil dari https://doi.org/10.7717/peerj.1089

Yuwono, S. (2009, November 11). Islam dan fenomena mutakhir Indonesia. Harian Joglosemar, 8. 